\title{
KORELASI PENDAPATAN EKONOMI DAN KEDEWASAAN PASANGAN TERHADAP KEHARMONISAN RUMAH TANGGA PELAKU PERNIKAHAN DI BAWAH UMUR DI DESA WEDUSAN, TIRIS, PROBOLINGGO
}

Umar Faruq Thohir

\begin{abstract}
:
Marriage is the inner bond between a man and a woman as husband and wife in order to form a happy and eternal family (household) based on the One Godhead. According to Wahbah az-Zuhaili in his book al-Fiqh al-Islâmî wa adillatuh that marriage is a contract that has been established by syara 'that a man may benefit to do a special (intercourse) with a woman or vice versa.
\end{abstract}

Keywords: Marriage, Ekonomic, Household

* Dosen tetap Fak. Syariah INZAH Genggong Kraksaan 


\section{A. Latar Belakang}

Perkawinan ialah ikatan lahir batin antara seorang pria dengan seorang wanita sebagai suami istri dengan tujuan untuk membentuk keluarga (rumah tangga) yang bahagia dan kekal berdasarkan Ketuhanan Yang Maha Esa. ${ }^{1}$ Menurut Wahbah az-Zuhailî dalam kitabnya alFiqh al-Islâmî wa adillatuh bahwa pernikahan adalah akad yang telah ditetapkan oleh syara' agar seorang laki-laki dapat mengambil manfaat untuk melakukan istimt $\hat{a}$ ' (persetubuhan) dengan seorang wanita atau sebaliknya ${ }^{2}$. Nabi Muhammad bersabda: ${ }^{3}$

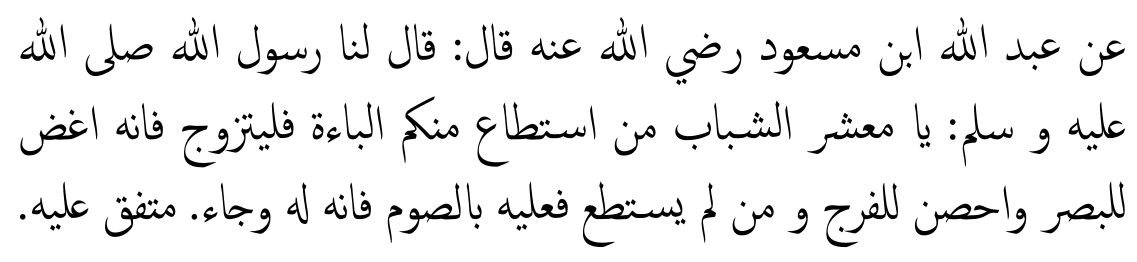

Dalam pernikahan, semua pasangan pasti memiliki keinginan untuk mewujudkan keharmonisan dalam rumah tangga mereka. Banyak yang berhasil mewujudkannya, namun juga banyak yang gagal meraihnya, bahkan tidak sedikit yang berujung pada perceraian.

Syahrin Harahap merumuskan kriteria keluarga bahagia (sakinah) setidaknya memiliki sepuluh ciri, yaitu :

1. Saling menghormati dan saling menghargai antara suami istri, sehingga terbina kehidupan yang rukun dan damai.

2. Setia dan saling mencintai sehingga dapat dicapai ketenangan dan keamanan lahir batin yang menjadi pokok kekalnya hubungan.

1 Pasal 1 Undang-Undang Nomor 1 Tahun 1974. Selanjutnya dalam Penelitian ini, penyusun menggunakan istilah Undang-Undang Perkawinan, bukan UndangUndang No. 1 Tahun 1974, agar lebih mempermudah pemahaman dan penyeragaman istilah.

2 Zuhailî az-, Wahbah, 1989, al-Figh al-Islâmî wa adillatuhu, cet. Ke-3, Beirut: Dâr al-Fikr, VII:29

3 Artinya: Dari Abdullah Ibn Masud R.A. berkata: Rasulullah Saw. Bersabda kepada kami: Wahai para pemuda, barang siapa di antara kalian yang memiliki kemampuan, hendaklah ia menikah, karena sesungguhnya pernikahan itu lebih menundukkan pandangan dan lebih menjaga kemaluan. dan barang siapa yang tidak memiliki kemampuan untuk menikah, maka ia harus berpuasa, karena sesungguhnya puasa itu dapat dijadikan sebagai obat (al-Bukhârî, t.t.: VI:143). Dalam Sunân atTirmidzî juga ditemukan hadits yang memiliki kesamaan kandungan hadits, tapi berbeda dalam redaksi matannya (at-Tirmidzî, t.t.: II:373). 
3. Mampu menghadapi segala persoalan dan segala kesukaran dengan arif dan bijaksana, tidak terburu-buru, tidak saling menyalahkan dan mencari jalan keluar dengan kepala dingin.

4. Saling mempercayai, tidak melakukan hal yang menimbulkan kecurigaan dan kegelisahan.

5. Saling memahami kelebihan dan kekurangan.

6. Konsultatif dan musyawarah, tidak segan minta maaf jika bersalah.

7. Tidak menyulitkan dan menyiksa pikiran tetapi secara lapang dada dan terbuka.

8. Dapat mengusahakan sumber penghasilan yang layak bagi seluruh keluarga.

9. Semua anggota keluarga memenuhi kebahagiaannya.

10. Menikmati hiburan yang layak. (Harahap, 1996: 164).

Sedangkan menurut Ahmad Kamaludiningrat (1993: 40), keluarga yang harmonis adalah keluarga yang diawali dengan pernikahan yang sah secara Islam dan berkualitas, yaitu:

1. Perkawinan yang diniati karena agama, yaitu perkawinan sesama muslim untuk mencapai ketakwaan suami istri dan keturunan.

2. Calon suami istri sedapat mungkin berkemampuan baik fisik, mental maupun ekonomi atau materi.

3. Diusahakan adanya keseimbangan (kafaah) antara calon suami dan istri.

Kriteria-kriteria tersebut tentunya masih dapat didiskusikan kembali, namun setidaknya, hal itu menunjukkan bahwa ternyata untuk mewujudkan rumah tangga yang harmonis bukanlah perkara yang mudah. Setelah akad pernikahan, kedua belah pihak akan menerima beban yang berat dan tanggung jawab masing-masing. Tanggung jawab dan beban itu bukanlah sesuatu yang mudah dilaksanakan, sehingga mereka harus sanggup memikul dan melaksanakannya (Amir Nuruddin dan Azhari Akmal Taringan, 2004: 39).

Hanya mereka yang telah dewasa saja yang secara umum dapat melewatinya, sedangkan mereka yang belum dewasa, belum siap menerima beban seberat ini. Akan tetapi, dalam keseharian, peristiwa perkawinan usia di bawah umur sering kali ditemukan, terutama di 
dalam masyarakat pedesaan atau masyarakat berpendidikan rendah. Alasan yang klise dalam perkawinan ini adalah kesulitan ekonomi, serta kebisaaan adat yang terjadi pada keluarga yang merasa malu mempunyai anak gadis yang belum menikah di usia dua belas sampai lima belas tahun bahkan lebih rendah lagi. Biasanya perkawinan seperti ini berusia pendek karena mereka yang terlibat perkawinan tersebut memang belum siap lahir batin untuk menghadapinya (Hakim, 2000: 142).

NJ. Aisjah Dahlan mengkhawatirkan orang yang menikah pada usia di bawah umur dapat menjalin hubungan yang harmonis, karena mereka masih belum dewasa dan belum mapan secara ekonomi, bahkan NJ. Aisjah Dahlan menegaskan, hanya orang dewasa yang secara umum dapat mewujudkannya (Dachlan, 1969: 52-53).

Terlepas dari hal itu semua, fakta di lapangan (based on fact), seperti yang terjadi di Desa Wedusan, Kecamatan Tiris, Kabupaten Probolinggo, ${ }^{4}$ menunjukkan bahwa ditemukan banyak sekali pernikahan yang dilakukan oleh calon mempelai dengan usia di bawah batas minimal standar usia yang telah diatur dalam Undang-Undang Perkawinan. ${ }^{5}$

Desa Wedusan merupakan desa yang terletak di pegunungan, dengan jalan berbatu cadas dan susah air. Desa ini merupakan desa terpelosok, jauh dari perkotaan, tidak ada angkutan desa, bahkan mobil susah masuk ke desa ini. Mayoritas masyarakat desa ini bertani dan berkebun. Sebagian besar masyarakat desa ini hanya lulusan Sekolah Dasar, bahkan ada yang tidak sekolah.

Melihat kenyataan yang massif tersebut, nampaknya persoalan ekonomi dan kedewasaan pasangan bukanlah masalah yang signifikan bagi pasangan pernikahan di bawah umur di Desa Wedusan ini yang secara umum dianggap memiliki pengaruh terhadap keharmonisan rumah tangga. Hal itu terbukti, setidaknya, dari animo masyarakat yang tetap mengafirmasi praktek pernikahan di bawah umur ini.

4 Demi efisiensi bahasa, selanjutnya dalam Penelitian ini hanya disebut Desa Bicabbi saja, tanpa menggunakan Kecamatan dan Kabupaten lagi.

5 Undang-Undang Perkawinan dengan prinsip kematangan calon mempelai menetapkan batas usia 19 tahun bagi pria dan 16 tahun bagi wanita sebagai batas minimal melangsungkan pernikahan. Sebagaimana dijelaskan dalam pasal 7 ayat (1). Meski demikian, dalam keadaan yang sangat memaksa, pernikahan di bawah umur tersebut dapat dimungkinkan, tetapi setelah memperoleh dispensasi dari Pengadilan atas permintaan kedua orang tua yang bersangkutan. Hal ini diatur dalam UndangUndang Perkawinan pasal 7 ayat (2). 
Memperhatikan hal itu semua, maka penilitian ini akan dilakukan untuk meneliti adakah hubungan antara pendapatan ekonomi dan kedewasaan pasangan terhadap pelaku pernikahan di bawah umur di Desa Wedusan, Kecamatan Tiris, Kabupaten Probolinggo.

\section{B. Terminologi Pernikahan di bawah Umur}

Menurut Rahmat Hakim, Pernikahan adalah suatu akad yang menyebabkan kebolehan bergaul antara seorang laki-laki dengan seorang wanita dan saling menolong diantara keduanya serta menentukan batas hak dan kewajiban di antara keduanya (Hakim, 2000: 142).

Definisi tersebut, disamping mengandung kebolehan hubungan seksual, juga menyiratkan bahwa pernikahan mengandung aspek hukum dan aspek ta'âwun (gotong-royong). Akibatnya, pelaku pernikahan dihadapkan kepada tanggung jawab serta hak-hak yang dimilikinya.

Pengertian tersebut selaras dengan pengertian yang diinginkan Undang-Undang Perkawinan yang termuat dalam pasal 1, yang selengkapnya berbunyi "Perkawinan ialah ikatan lahir batin antara seorang pria dengan seorang wanita sebagai suami istri dengan tujuan membentuk sebuah keluarga (rumah tangga) yang bahagia, kekal, berdasarkan Ketuhanan Yang Maha Esa."

Dari beberapa pengertian diatas, dapat disimpulkan bahwa pernikahan adalah akad antara pria dan wanita untuk saling memiliki dan bersenang-senang dan menghalalkan pergaulan suami-istri dalam rangka membentuk keluarga dan rumah tangga yang sakinah, ${ }^{6}$ mawaddah dan penuh rahmah.

Sedangkan pernikahan di bawah umur yang dimaksud dalam penelitian ini adalah pernikahan yang dilakukan di bawah usia standar Undang-Undang Pernikahan, yaitu apabila calon suami berada di bawah usia sembilan belas tahun dan atau calon istri berada di bawah

6 Kata sakinah berasal dari kata سكن yang berarti tenang; tidak bergerak; diam (Yunus, 1989: 174). Oleh karena itulah, menurut Khoiruddin Nasution (2005: 39), pernikahan adalah pertemuan antara pria dan wanita yang kemudian menjadikan (beralih) kerisauan antara keduanya menjadi ketentraman atau sakinah menurut bahasa al-Qur'an (Ar-Rûm (30): 21). Menurut Quraish Shihab, pisau disebut sikkîn karena pisau adalah alat sembelih yang dapat menjadikan binatang yang disembelih tenang (Shihab, 1996: 192). 
usia enam belas tahun. Hal ini diatur dalam pasal 7 ayat (1) UndangUndang Pernikahan dan pasal 15 ayat (1) Kompilasi Hukum Islam.

Sebenarnya ada istilah lain yang juga digunakan untuk menjelaskan tentang pernikahan di bawah umur, yaitu pernikahan dini. Keduanya sama-sama menunjukkan tentang pernikahan yang dilakukan pada usia awal. Hanya saja, kata dini dalam pernikahan dini menunjukkan keumuman dari semua pernikahan yang dilakukan pada usia awal pertumbuhan manusia (usia dini) yang cenderung tidak memiliki batasan kualifikasi usia yang pasti.

Dalam Psikologi Perkembangan, tidak terdapat penggolongan rentang perkembangan kejiwaan manusia menjadi usia dini, usia tengah, dan usia lanjut. Pembagian rentang perkembangan kejiwaan manusia setidaknya dalam psikologi adalah masa bayi, anak-anak, remaja, dewasa, dan tua (Carol K. Sigelman dan David R. Shaffer, 1995: 122). Namun dalam dunia pendidikan, kata usia dini mengindikasikan pendidikan bagi siswa berusia balita (Bawah Lima Tahun), seperti dalam istilah jenis Lembaga Pendidikan Anak Usia Dini (PAUD). ${ }^{7}$ Sedangkan jika menggunakan istilah pernikahan di bawah umur, maka maksudnya jelas, yaitu semua pernikahan yang dilakukan di bawah batas minimal usia menikah sebagaimana diatur dalam pasal 7 ayat (1) Undang-Undang Perkawinan dan pasal 15 ayat (1) Kompilasi Hukum Islam. Oleh karena itulah, peneliti lebih cenderung pada istilah pernikahan di bawah umur dari pada pernikahan dini (Mahmood, 1972: 194; Ramulyo, 1984: 183184; Sosroatmodjo dan A. Wasit Aulawi, 1978: 35). ${ }^{8}$

7 Hal itu juga terlihat dari beberapa istilah yang yang sering dipakai dalam kegiatan yang terkait dengan pendidikan usia anak di bawah lima tahun. Seperti program "Pelatihan 2 Hari; Pentingnya Pendidikan Usia Dini" yang digelar oleh Budi Mulia Dua Foundation pada 17 Maret 2011 di Condong Catur, Sleman, Yogyakarta, dimana program itu diadakan khusus untuk para pengajar pendidikan usia dini (bawah lima tahun) (Dinas Pendidikan Forum PAUD, 2006: 25).

8 Istilah pernikahan di bawah umur juga dipakai oleh Pengadilan Agama Sumenep untuk mendata penduduk yang bercerai akibat melakukan pernikahan di bawah batas minimal usia nikah menurut Undang-Undang Perkawinan (BPS Kabupaten Sumenep, 2006: 97-98). 


\section{Usia Ideal Pernikahan; Tinjauan (Singkat) Ekonomi Sosial, Psikologi, dan Biologi}

Orang yang melangsungkan sebuah pernikahan bukan hanya semata-mata untuk memuaskan nafsu birahi yang bertengger dalam tubuh dan jiwanya, melainkan untuk meraih ketenangan, ketentraman dan sikap saling mengayomi di antara suami istri dengan dilandasi cinta dan kasih sayang yang mendalam. Di samping itu, untuk menjalin tali persaudaraan di antara dua keluarga dari pihak suami dan pihak istri dengan berlandaskan pada etika dan estetika yang bernuansa ukhuwah basyâriyah dan islâmiyah (Asmawi, 2004: 19). Jadi tujuan yang hakiki dalam sebuah pernikahan adalah mewujudkan mahligai rumah tangga yang sakinah yang selalu dihiasi mawaddah dan rahmah.

Namun dalam proses mewujudkan tujuan luhur pernikahan tersebut, terkadang suami dan istri dihadapkan pada cobaan-cobaan atau rintangan baik yang datangnya dari internal keluarga sendiri maupun dari eksternal keluarga. Oleh karena itulah kedewasaan penting dalam pernikahan ini, karena orang yang dewasa mampu menilai diri secara realistik, dapat mengontrol emosi, orientatif (memiliki tujuan), menerima tanggung jawab, dan mandiri (Desmita, 2005: 241.242). Hal ini menjadi penting karena pernikahan harus dilakukan dengan kesadaran dan penuh tanggung jawab.

Perkembangan usia ideal menikah sangatlah terkait dengan perkembangan jiwa manusia sejak ia lahir sampai menjadi dewasa. Dalam psikologi, perkembangan jiwa manusia terbagi menjadi beberapa tahap, yaitu masa bayi, ${ }^{9}$ masa anak-anak, masa remaja, masa dewasa, dan masa tua. Perkembangan kejiwaan manusia tersebut juga bersamaan dengan pertumbuhan fisiknya. ${ }^{10}$

9 Menurut Jersild dalam bukunya Child Psychology menjelaskan bahwa perkembangan manusia dimulai sejak dalam kandungan. Anak yang mendapatkan gizi yang cukup, akan tumbuh secara optimal setelah lahir. Anak yang dalam masa kandungannya sering mendengarkan musik, ketika tumbuh besar dia akan senang kepada musik (Jersild, 1962: 20-21).

${ }^{10}$ Setiap aspek perkembangan individu, baik fisik, emosi, inteligensi, maupun sosial, satu sama lainnya saling mempengaruhi. Apabila seorang anak dalam pertumbuhan fisiknya mengalami gangguan (sering sakit-sakitan), maka dia akan mengalami kemandegan (hambatan) dalam perkembangan aspek lainnya, sepeti kecerdasannya kurang berkembang dan mengalami kelabilan emosional (Yusuf, 2004: 17). 
Pada masa bayi, manusia hanya bisa mengandalkan indranya (Santrock, 2002: 151-153), bayi hanya dapat mengungkapkan perasaan senang dan tidak senang, perasaan aman dan ketakutan. Hal itu ditunjukkannya melalui tangis dan tawa. Bayi menangis karena ada sesuatu yang membuatnya tidak nyaman, dan bayi tertawa karena ada pengaruh yang membuatnya riang. Bayi belum pandai menyatakan keinginannya, ia hanya pandai menangis (Zulkifli L., 2006: 22). Masa bayi ini berlangsung sampai berusia satu tahun.

Pada masa anak-anak, manusia masih sangat tergantung kepada orang-orang terdekat di rumahnya, seperti orang tua, kakak, dan siapapun yang lebih dewasa. Keputusannya dalam memilih masih membutuhkan pertimbangan dan anjuran orang tua (Desmita, 2005: 183-184). Anak pada masa ini suka meniru tingkah laku orang-orang yang dilihatnya (imitatif). Terkadang anak sangat berobsesi untuk menjadi seperti yang ditonton di televisi. Pada masa naka-anak, manusia sangatlah dipengaruhi oleh lingkungannya, seperti keluarga dan teman-teman bermainnya atau teman-teman di sekolahnya. Pada masa akhir anak-anak, anak cenderung keras kepala, suka membantah dan membandel. Masa anak-anak ini sejak berusia satu tahun sampai berusia dua belas tahun (Daradjat, 1970: 109-114).

Berikutnya masa remaja. Manusia pada masa ini sudah mulai berpikir kritis, suka menentang tradisi, mengira dirinya mampu menentukan pendapatnya tentang segala masalah kehidupan, padahal justru membuat keseimbangan jiwanya terganggu (Santrock, 2003: 93). Manusia pada saat remaja menganggap keterangan orang tua sebagai pertimbangan, bukan lagi sesuatu yang harus dipatuhi secara mutlak, cenderung egosentris dan sangat subyektif, ${ }^{11}$ seolah merasa dirinya selalu pada posisi yang benar. Masa remaja ini berlangsung sejak seseorang berusia dua belas tahun sampai 20 tahun (Desmita, 2005: 189-190).

${ }^{11}$ Menurut Carl Gustav Jung, berdasarkan reaksi terhadap lingkungan, kepribadian itu terbagi menjadi (1) extrovert, yaitu kepribadian yang terbuka, suka mendapatkan masukan dari orang lain. (2) introvert, yaitu kepribadian yang tertutup, lebih banyak berorientasi kepada diri sendiri. (3) ambivert, yaitu tipe kepribadian yang tidak dapat digolongkan ke dalam tipe extrovert maupun introvert (Sarwono, 1978: 190; Chaplin, 2006: 184). Subyektif di sini sama dengan introvert yang dimaksud Jung, yang berarti "menurut pandangan sendiri (Partanto dan M. Dahlan Al-Barry, 1994: 730). 
Jika pada masa remaja manusia suka mengkritik dan cenderung subyektif, maka pada masa dewasa manusia sudah mencapai perpaduan antara keseimbangan dirinya sendiri dengan pengaruh dunia lingkungan. Mereka membentuk pribadi yang matang, menerima norma-norma budaya dan kehidupan (Zulkifli L., 2006: 20). Masa dewasa adalah puncak dari perkembangan kejiwaan manusia. Orang yang telah dewasa mempunyai ketentraman jiwa, ketetapan hati dan kepercayaan yang tegas (Zakiah Daradjat, Ilmu Djiwa, 1970: 136). Menurut Andi Mappiare (1983: 17), Orang dewasa memiliki sikap obyektif, yaitu berusaha mencapai keputusan dalam keadaan yang bersesuain dengan kenyataan. Selama periode dewasa ini, orang melibatkan diri secara khusus dalam karir, pernikahan, dan hidup berkeluarga. Menurut Erikson, perkembangan psikososial selama masa dewasa ditandai dengan tiga gejala penting, yaitu keintiman, generatif, dan integritas (Desmita, Psikologi Perkembangan, 2005: 242). Usia seseorang pada masa dewasa ini berkisar antara usia dua puluh satu tahun sampai sekitar usia enam puluh lima tahun (Fieldman, 1996: 93-94).

Jika pada masa dewasa kemampuan otak manusia melebihi kepandaian orang yang lebih tua, maka pada masa tua, kemampuan otak dalam menganalisa sudah mulai menurun, tubuh perlahan-lahan menua, lapisan tulang rawan menjadi keras dan rusak, otot-otot mulai mengendur, tubuh kurang bisa menyesuaikan diri, lebih cepat merasa letih, reaksinya lebih lamban, dan daya tahan terhadap penyakit semakin merosot (Zulkifli L., Psikologi Perkembangan, 2006: 7). Pada masa tua ini, daya ingatan seseorang sudah mulai melemah dan sulit sekali untuk belajar dan mengingat infomasi tertentu (Osho, 2004: 170). Orang tua lebih suka mengalah, bijaksana, lebih suka mencari ketenangan dan menggunakan waktu luang untuk introspeksi (Malcolm Hardy dan Steve Heyes, 1985: 185). Masa tua ini dimulai sejak usia enam puluh lima tahun sampai meninggal (Desmita, 2005: 234).

Dari beberapa uraian mengenai tahapan perkembangan kejiwaan manusia, mulai dari masa bayi sampai masa tua tersebut, dapat disimpulkan bahwa sebenarnya masa yang ideal untuk menikah adalah masa dewasa. ${ }^{12}$ Karena pada masa dewasa, perkembangan psikis manusia

${ }^{12}$ Orang yang sudah dewasa sudah banyak mempersiapkan hidup berkeluarga, memilih teman bergaul, sebagai calon suami atau isteri (Mappiare, 1983: 140). 
berada dalam masa puncak kematangannya (Witherington, 1982: 140145). Dapat dikatakan bahwa seseorang yang menikah di bawah usia dua puluh tahun adalah belum dewasa, karena usia dewasa secara Psikologi adalah ketika seseorang mencapai usia sekitar dua puluh tahun. ${ }^{13}$

Demikian juga dalam hal ekonomi, pada usia dewasa, seseorang sudah memiliki keinginan lebih untuk mandiri. Pada masa dewasa, seseorang bahkan sudah benar-benar memiliki cita-cita membahagiakan orang tuanya dengan membelikan sesuatu yang diinginkan orang tuanya.

Pada usia remaja, seseorang hanya ego dalam hal ekonomi. Remaja hanya berkata seolah meyakinkan dirinya bahwa dirinya mampu hidup mandiri secara ekonomi, padahal tidak. Hal itu karena mereka terinspirasi melihat orang dewasa dapat hidup mandiri, namun inspirasi itu tidak ditopang oleh dasar pendapatan ekonomi yang kuat, layaknya dewasa. ${ }^{14}$

\section{Pendapatan Ekonomi dalam Rumah Tangga}

Persoalan pendapatan ekonomi merupakan salah satu hal penting yang harus diperhatikan dalam rumah tangga, termasuk juga rumah tangga pasangan pernikahan di bawah umur. Banyak perceraian terjadi karena kebutuhan ekonomi rumah tangga yang tidak terpenuhi secara maksimal (Indra, dkk., 2004: 222-223).

13 Begitu pula dalam Biologi, menurut Hakimi (1990: 49-55), kehamilan pada usia yang relatif muda itu tidak baik bagi kandungan, karena meski rahim (uterus) sudah dapat dibuahi, namun belum cukup kuat akibat usia yang masih terlalu muda. Menurut Rustam (1989: 200-201), "Jika hal ini diabaikan, ditakutkan terjadi prematur, atau hal-hal lain yang menyebabkan maternal atau perinatal." Lebih jelas lagi menurut dr. Ediati Triningsih (dokter dari Yayasan Kanker Indonesia), "Penyebab utama kanker serviks adalah infeksi human papilloma virus (HPV). Adapun faktor yang menyebabkan terjangkitnya virus HPV ini adalah aktifitas seksual pertama dilakukan sebelum berusia 18 tahun, sistem daya tahan menurun, pasangan seksual banyak, merokok, kebersihan buruk, banyak anak, dan infeksi seperti GO, sifilis, HIV/AIDS atau chlamyda. " Lihat Fadmi Sustiwi, "Antisipasi Kanker Serviks dengan Pap-Smear," Kedaulatan Rakyat, (Senin, 19 Januari 2009), hlm. 14.

${ }^{14}$ Teens tend to be less able than adults to access accurately themselves and their environments, to plan ahead, to anticipate the consequences of their actions, and to develop realistic expectations. Wishful thinking is common. As a result, they often have an inflated sense of power. Although they may not have the financial, emotional, or family resources to care for a child, they confidently assume, they have an ability to do so. "I can handle it" is a common refrain (Mc Bee, 1982: 9). 
Menurut Syahrin Harahap, untuk dapat mewujudkan rumah tangga yang harmonis harus dapat mengusahakan sumber penghasilan yang layak bagi seluruh keluarga (Harahap, 1996: 164). Pendapat ini juga diperkuat oleh Ahmad Kamaludiningrat (1993: 40) yang mengatakan bahwa calon suami istreri sedapat mungkin berkemampuan baik fisik, mental maupun ekonomi atau materi.

Pernyataan tersebut menegaskan bahwa secara teoritik, terdapat hubungan antara pendapatan ekonomi dengan keharmonisan keluarga. Hal ini menunjukkan bahwa semakin pasangan suami isteri memiliki pendapatan ekonomi yang lebih tinggi, maka semakin harmonis pula rumah tangga yang dibangunnya.

Oleh karena itulah, wajar jika pemerintah tidak melegalkan pernikahan dibawah umur, hal itu mempertimbangkan aspek pendapatan ekonomi, di mana rata-rata pelaku pernikahan di bawah umur bahkan belum memiliki pendapatan ekonomi yang jelas (Sosroatmodjo dan H.A. Wasit Aulawi, 1978: 35-38).

Untuk memudahkan penelitian dalam menentukan kriteria pendapatan ekonomi, maka ketentuan pendapatan ekonomi diukur dari kemampuan pendapatan ekonomi setelah dikurangi pengeluaran kebutuhan rumah tangga, mencukupi atau tidak.

\section{E. Pentingnya Kedewasaan Pasangan dalam Rumah Tangga}

Pernikahan merupakan ikatan kokoh yang dibina oleh pasangan suami isteri untuk membangun rumah tangga yang harmonis. Keharmonisan rumah tangga dapat terwujud dalam kecocokan dan kekompakan pasangan suami isteri. Menurut Thariq Kamal anNu'aimi, pasangan harus bisa mengatur manajemen ketidakcocokan dalam perkawinan. Pasangan harus bisa memahami bahwa tabiat lakilaki (suami) maupun perempuan (istri) memang berbeda, baik secara psikologis maupun seksual. Dengan mengerti dan memahaminya akan mampu membangun kehidupan perkawinan yang romantis, harmonis, dan bahagia selamanya. Dengan memahami tabiat yang berbeda antara suami istri, maka hal itu akan meringankan beban kegelisahan, kemarahan, kejengkelan, dan aneka beban lainnya (an-Nu'aimi, 2005: 1-11). 
Jika demikian, maka untuk mewujudkan keharmonisan rumah tangga dibutuhkan sosok pasangan yang suka mengalah, tidak pemarah, dan pengertian, dimana dalam psikologi hal itu dimiliki oleh orang yang telah dewasa. Pada saat anak-anak, seseorang masih sangat imitatif, dan pada saat remaja, seseorang sangat egois, dan pada saat dewasa, seseorang sudah mandiri, bisa mengalah, dan menghargai orang lain (Osho, 2004: 170; Malcolm Hardy dan Steve Heyes, 1985: 185).

Oleh karena itulah, dapat disimpulkan secara teoritik bahwa semakin pasangan suami isteri dewasa, semakin harmonis pula hubungan rumah tangga mereka.

Sebenarnya kedewasaan memang tidak dapat diukur dengan usia, karena bisa jadi seseorang masih tergolong remaja, namun pemikirannya sudah dewasa, demikian juga banyak orang berusia dewasa, namun sikapnya masih egois seperti remaja. Namun karena mengukur kedewasaan sangatlah susah apalagi sejenis penelitian yang singkat ini, maka peneliti menggunakan indikasi usia untuk menetukan kedewasaan, yaitu merentang antara usia 25 sampai 45 tahun.

\section{F. Keharmonisan Rumah Tangga}

Harmonis adalah perpaduan berbagai warna karakter yang membentuk kekuatan eksistensi sebuah benda. Perpaduan inilah yang membuat warna apapun bisa cocok menjadi rangkaian yang indah dan serasi. Menurut Peter Salim dan Yenny Salim, keharmonisan memiliki kesamaan definisi dengan keserasian, keselarasan, dan kecocokan (Peter Salim dan Yenny Salim, 1991: 510)

Warna hitam, misalnya, kala berdiri sendiri akan menimbulkan kesan suram dan dingin. Jarang orang menyukai warna hitam secara berdiri sendiri. Tapi, jika berpadu dengan warna putih, akan memberikan corak tersendiri yang bisa menghilangkan kesan suram dan dingin tadi. Perpaduan hitam-putih jika ditata secara apik, akan menimbulkan kesan dinamis, gairah, dan hangat.

Seperti itulah seharusnya rumah tangga dikelola. Rumah tangga merupakan perpaduan antara berbagai warna karakter. Ada karakter pria, wanita, anak-anak, bahkan mertua. Dan tak ada satupun manusia di dunia ini yang bisa menjamin bahwa semua karakter itu sempurna. 
Pasti ada kelebihan dan kekurangan. Menurut Thariq Kamal anNu'aimi, pasangan harus bisa mengatur manajemen ketidakcocokan dalam perkawinan. Pasangan harus bisa memahami bahwa tabiat lakilaki (suami) maupun perempuan (istri) memang berbeda, baik secara psikologis maupun seksual. Dengan mengerti dan memahaminya akan mampu membangun kehidupan perkawinan yang romantis, harmonis, dan bahagia selamanya. Dengan memahami tabiat yang berbeda antara suami istri, maka hal itu akan meringankan beban kegelisahan, kemarahan, kejengkelan, dan aneka beban lainnya (an-Nu'aimi, 2005: 1-11).

Dalam rumah tangga, segala kekurangan dan kelebihan saling berpadu. Kadang pihak suami bernada rendah, kadang istri bernada tinggi. Di sinilah suami-istri dituntut untuk menciptakan keharmonisan dengan mengisi kekosongan yang ada diantara mereka. Menurut David Knox, Agar pasangan selalu kompak, maka pasangan itu diharuskan selalu melakukan komunikasi interaktif antar pasangan (Knox, t.t.: 353-354).

Menurut F. Ivan Nye, dengan teori Role Conceptnya menyatakan bahwa anggota keluarga harus mengerti peran masing-masing. Dengan mengetahui peran masing-masing, maka tidak akan terjadi tumpang tindih peran dalam keluarga. Jika suami berperan sebagai pemimpin rumah tangga, maka suami akan mengurusi hal-hal yang berkaitan dengan pengambilan kebijakan umum rumah tangga. Istri yang sudah mengerti bahwa suaminya yang berperan sebagai pemimpin rumah tangga, maka istri tidak akan berperan sebagai pemimpin juga, melainkan menjadi pengurus internal rumah tangga mengambil peran domestik keluarga (Nye, 1976: 15-23).

Sedangkan menurut Ahmad Kamaludiningrat (1993: 40), criteria keluarga yang harmonis adalah:

1. Perkawinan yang diniati karena agama, yaitu perkawinan sesama muslim untuk mencapai ketakwaan suami istri dan keturunan.

2. Calon suami istri sedapat mungkin berkemampuan baik fisik, mental maupun ekonomi atau materi.

3. Diusahakan adanya keseimbangan (kafaah) antara calon suami dan istri 


\section{G. Profil dan Tipologi Masyarakat Desa Wedusan}

Desa Wedusan adalah desa yang terletak di daerah pegunungan bebatuan. Air bersih sulit didapat. Untuk mandi, masyarakat harus ke sungai yang jaraknya cukup jauh dari pemukiman. Tempat yang terpelosok membuat transformasi budaya menjadi sedikit terhambat. Akibatnya, masyarakat banyak yang terbelakang dalam hal pendidikan. Bahkan, kalau memiliki anak perempuan, selepas mengenyam pendidikan Sekolah Dasar, masyarakat ingin segera menikahkan puterinya, karena sudah tidak ada kegiatan lagi baginya.

Masyarakat Desa Wedusan, bahkan terbiasa mandi bersama di sungai. Laki-laki dan perempuan mandi bersama-sama tanpa tabir. Mereka tidak lagi memperhatikan batasan aurat, karena yang terpenting bagi mereka adalah mandi dengan air melimpah. "Penduduk di sini kalau mandi ke sungai ini dah mas. Soalnya air tidak sampai ke rumah-rumah dan kalau ngebor terlalu dalam, biayanya mahal." Demikian kata Mujammil. ${ }^{15}$

Seperti daerah pegunungan terpencil lainnya, pendidikan di Desa ini kurang begitu digalakkan. Pemuda desa lebih memilih untuk bekerja sejak remaja dari pada melanjutkan sekolah, karena bekerja langsung menghasilkan uang dan sekolah belum tentu mendapatkan pekerjaan. "Dari pada menguliahkan anak, mending dipake untuk beli sapi mas, langsung diternak dan hasilnya langsung bisa kelihatan. Kalau sekolah, saat ini enggak menjamin mas." Demikian kata Abdul Mujib. ${ }^{16}$

Secara administratif, Desa Wedusan merupakan salah satu dari 16 desa yang masuk ke wilayah Kecamatan Tiris Kabupaten Probolinggo. Letaknya di paling tengah selatan dari Kota Probolinggo yang sebelah Utaranya berbatasan dengan Desa Racek, sebelah Timurnya berbatasan dengan Desa Kertosuko, sebelah Selatannya berbatasan dengan Desa Jangkang, dan sebelah Baratnya berbatasan dengan Desa Maron.

Luas wilayah Desa Wedusan adalah 919,800 hektare dengan areal sawah 27,000 hektare dan luas tanah keringnya mencapai 186.000 hektare. Sedangkan Jumlah penduduk desa ini adalah 3.829 jiwa. Desa dengan Jumlah penduduk sebanyak ini hanya memiliki 3 Raudhatul

15 Wawancara dengan Mujammil, Pelaku Pernikahan di bawah umur, Wedusan, Tiris, Probolinggo, tanggal 21 Desember 2015.

16 Wawancara dengan Abdul Mujib, Petani, Wedusan, Tiris, Probolinggo, tanggal 21 Desember 2015. 
Athfal, 3 Madrasah Ibidaiyah, 1 Sekolah Dasar Negeri, 3 Madrasah Tsanawiyah, 1 Sekolah Menengah Pertama dan 3 Madrasah Aliyah. Itupun rata-rata siswa yang sekolah dalam setiap kelasnya hanya berisi sekitar 10 siswa.

Berdasarkan data dari Kantor Urusan Agama Kecamatan Tiris. Setiap tahun rata-rata calon mempelai yang menikah di KUA Kecamatan Tiris yang berasal dari Desa Wedusan hanyalah 10,77\% saja. Jumlah pernikahan yang didaftarkan di KUA Kecamatan Tiris ini sejak tahun 2013 menunjukkan angka penurunan, pada tahun 2013 terdaftar 201 pernikahan, 12,94\% dari pernikahan tersebut berasal dari Desa Wedusan, dan pada tahun 2014, dari 164 pernikahan yang didaftarkan, 8,6\% diantaranya berasal dari Desa Wedusan. ${ }^{17}$

Namun demikian, menurut Kepala Desa Wedusan, rata-rata pernikahan yang dilakukan di luar sepengetahuan petugas pencatat pernikahan adalah sekitar 20 sampai 30 pasangan dalam setiap tahunnya, dan hampir dari jumlah tersebut semuanya adalah pernikahan yang dilakukan di bawah umur, karena pernikahan pertama rata-rata penduduk di sini adalah pada usia sekolah. Kalau ada pernikahan yang dilakukan pada saat usia tua, biasanya mereka duda atau janda. ${ }^{18}$

Berdasarkan kondisi topografis dan lingkungan seperti di atas, tepat sekali jika mereka memilih tawakkal dalam keseharian, bahkan kata Fahim, "Kami ini kan orang desa, jadi jangan disamakan dengan gaya hidup orang kota. Kehidupan seperti ini sudah cukup bagi kami."19

Selain merasa cukup, para pelaku pernikahan di bawah umur di desa Wedusan juga bertawakkal kepada Allah, sehingga meskipun menurut outsider mereka nampak kekurangan, tetapi sejatinya, kepasrahan mereka pada Tuhan membuat mereka menerima segalanya. "Kita harus bersyukur sudah diberi kehidupan yang seperti ini mas oleh Tuhan. Seandainya pun saya ditakdirkan lebih kurang lagi, saya akan tetap menerima. Karena manusia memang tidak bisa berbuat apa-apa. Semua sudah ada takdirnya."

${ }^{17}$ BPS Kabupaten Probolinggo, Kecamatan Tiris dalam Angka 2014, (Probolinggo: BPS Probolinggo, 2014), hlm. 27.

${ }_{18}$ Wawancara dengan Busri, Kepala Desa Wedusan, Desa Wedusan, Kecamatan Tiris, Kabupaten Probolinggo, Tanggal 21 Desember 2015.

${ }^{19}$ Wawancara dengan Ahmad Fahim, Pelaku Pernikahan di bawah Umur, Wedusan, Tiris, Probolinggo, tanggal 21 Desember 2015. 
Demikian kata Khotijah. ${ }^{20}$

Menurut pengamatan penyusun, sikap tawakkal sudah mendarah daging dan tidak pernah lepas dari keseharian para pelaku pernikahan di bawah umur di Desa Wedusan ini. Hal ini juga dikuatkan oleh Busri yang mengatakan "Para pelaku pernikahan di bawah umur di desa saya ini orangnya tawakkal-tawakkal mas. Kenyataannya saya tidak pernah mendengar mereka cekcok dalam rumah tangga gara-gara urusan dapur dan nampaknya mereka adem ayem saja. Saya yakin meski menikah muda, mereka juga telah mengerti resikonya." "dalam hidup kita harus bertawakkal, karena dalam hidup pasti ada resiko. Pembuat dan pengendali resiko itu adalah Tuhan, maka bertawakkal adalah memasrahkan resiko kembali kepada Tuhan. Menerima segala yang terjadi." Demikian kata Sunandar. ${ }^{22}$

\section{H. Faktor Penyebab Pernikahan di bawah Umur}

Faktor penyebab terjadinya pernikahan di bawah umur di Desa Wedusan adalah:

\section{Faktor Tradisi (Adat-Istiadat)}

Pernikahan di bawah umur di Desa Wedusan bukanlah hal yang tabu lagi, bahkan mereka senang kalau anaknya segera menikah. "Kalau punya anak yang masih belum menikah padahal sudah berusia belasan atau dua puluhan, rasanya terbebani, karena nanti akan menjadi omongan orang." Demikianlah alasan Ibu Khadijah menikahkan puteranya pada saat sedang duduk di bangku Sekolah Menengah Pertama (SMP) kelas dua. ${ }^{23}$

Pernikahan di bawah umur di Desa Wedusan sudah merupakan hal biasa dilakukan. Bahkan apabila ada anak gadis yang belum segera

20 Wawancara dengan Khotijah, Pelaku Pernikahan di bawah Umur, Wedusan, Tiris, Probolinggo, tanggal 21 Desember 2015.

${ }^{21}$ Wawancara dengan Busri, Kepala Desa Wedusan, Desa Wedusan, Kecamatan Tiris, Kabupaten Probolinggo, Tanggal 21 Desember 2015.

22 Wawancara dengan Sunandar, Pelaku Pernikahan di bawah Umur, Wedusan, Tiris, Probolinggo, tanggal 21 Desember 2015.

${ }^{23}$ Wawancara dengan Khadijah, Ibu Rumah Tangga, Wedusan, Tiris, Probolinggo, Tanggal 16 November 2015. 
menikah ditakut-takuti "mendapatkan gelar perawan tua." Anak-anak gadis di Desa ini sangatlah takut untuk dikatakan perawan tua.

Karena anggapan-anggapan dan berbagai predikat negatif inilah, pernikahan di bawah umur di Desa Wedusan ini tetap hidup dan dianggap bukanlah merupakan sesuatu yang janggal untuk dilakukan.

\section{Faktor Ekonomi}

Sebagaimana data yang diperoleh dari Badan Pusat Statistik Kabupaten Probolinggo, bahwa mayoritas sumber mata pencaharian masyarakat Desa Wedusan adalah bertani, ${ }^{24}$ sehingga omzet rata-rata rumah tangga disini relatif rendah. Posisi seperti inilah yang membuat orang tua merasa lepas tanggung-jawab apabila telah menikahkan anaknya, sebagaimana disampaikan bapak Kasmin:

"Kalau sudah menikahkan anak, berarti tanggung-jawab orang tua kan sudah hilang, karena agama kita mengharuskan mengasuh anak sampai bâlig, kalau sekolah ya sampai lulus, atau kalau paling tidak ya sampai menikah. Lebih cepat menikah, lebih awal kita lepas tanggung-jawab." 25

Kebanyakan yang menikah di bawah umur di Desa Wedusan adalah anak perempuan, ${ }^{26}$ dan budaya masyarakat setempat adalah patriarkat, sehingga beban perekonomian lebih dibebankan kepada suami. Oleh karena itu, orang tua yang memiliki puteri menikah di usia yang relatif muda merasa kehilangan beban tanggung-jawab menghidupi anaknya lebih awal. Dengan terjadinya pernikahan itu, dan adanya budaya patriarkat ini, maka praktis anak perempuan tersebut sudah menjadi tanggungan suami pasca dilaksanakannya akad pernikahan tersebut.

${ }^{24} 56,84 \%$ sumber mata pencaharian dari pertanian, 7,73\% sumber mata pencaharian dari perkebunan, $11,80 \%$ sumber mata pencaharian dari perikanan, $22,06 \%$ sumber mata pencaharian dari peternakan, 0,2 \% sumber mata pencaharian sebagai pemulung, 1,48\% sumber mata pencaharian dari pertukangan (BPS Kabupaten Probolinggo, 2014: 9).

${ }^{25}$ Wawancara dengan Kasmin, Orang tua pelaku Pernikahan di bawah Umur, Wedusan, Tiris, Probolinggo, 19 November 2015.

${ }^{26}$ Dari 43 kasus Pernikahan di bawah Umur yang berhasil penyususun temukan dan wawancara satu persatu, 37 diantaranya adalah sang istri yang masih tergolong di bawah standar batas minimal usia menikah, 6 diantaranya yang sama-sama di bawah umur. Data ini penyusun simpulkan dari hasil survey lanjutan. 
Selain itu, ada orang tua yang menerima tawaran menikah atau sengaja menikahkan puterinya kepada tokoh masyarakat atau orang yang dianggap kaya pada usia yang relatif muda. Hal ini dilakukan oleh orang tua agar anak perempuannya tersebut dapat memberikan uang (atau hadiah yang lain) kepadanya kelak. Namun pernikahan di bawah umur yang dilakukan dengan alasan seperti ini sangat sedikit. Dari 43 kasus yang ada, hanya ada 2 kasus yang bermodus seperti ini. "Awalnya saya tidak mau menikahkan anak saya dengannya, tapi saya yakin kalau dinikahkan dengannya anak saya bisa merasa cukup untuk memenuhi kebutuhan sehari-harinya, jadi saya relakan meski dia harus cepat berpisah dengan saya (menikah di bawah umur)."27

\section{Faktor Rendahnya Animo Masyarakat Terhadap Pendidikan}

Kalau berbicara pendidikan, rata-rata orang tua di Desa Wedusan yang hidup sampai tahun 2015 ini berpendidikan terakhir Sekolah Dasar (SD), ${ }^{28}$ bahkan dari 3.829 jumlah penduduk Desa Wedusan, hanya 13,3\%-nya saja, atau 413 penduduknya saja yang pernah bersekolah (BPS Kabupaten Probolinggo, 2010: 5 dan 13). Hal ini menunjukkan betapa animo masyarakat terhadap pendidikan di Desa ini masih sangat kurang. Mereka enggan menuntaskan pendidikan dasar (sampai Sekolah Menengah Atas) karena melihat orang-orang yang kaya di sekitar mereka bukanlah golongan yang berpendidikan tinggi. Dengan sangat meyakinkan,Ibu Toyyibah menjelaskan:

"Yang terpenting dalam hidup ini adalah bagaimana caranya bisa bertahan hidup dan bisa menghidupi anak dan istri, dan itu harus dengan bekerja bukan dengan sekolah, Pak H. Karim (mantan Kepala Desa Wedusan) aja cuma tamatan SD, tapi bisa kaya dan malah pernah jadi Kades selama dua dekade." ${ }^{29}$

Animo masyarakat yang sangat minim terhadap pendidikan ini membuat kader-kader muda jarang melihat pendidikan sebagai media

27 Wawancara dengan Musdarmin, Orang tua pelaku Pernikahan di bawah Umur, Wedusan, Tiris, Probolinggo, Tanggal 15 November 2015.

${ }^{28}$ Wawancara dengan Daryono, Sekretaris Desa Wedusan, Wedusan, Tiris, Probolinggo, tanggal 16 November 2015.

${ }^{29}$ Wawancara dengan Toyyibah, Buruh Tani dan pelaku Pernikahan di bawah Umur, Wedusan, Tiris, Probolinggo, tanggal 7 November 2015. 
menuju kesuksesan, atau setidaknya jalan untuk merubah pemikiran. Anak kelas 5 Sekolah Dasar biasanya sudah diajak untuk bernelayan atau bertani, sehingga mereka sudah merasa lebih senang untuk mendapatkan uang, dan tentunya mengenyampingkan pendidikan.

Kondisi seperti ini membuat pendidikan bukan sebagai prioritas, akhirnya anak (laki-laki) yang sudah bekerja berkeinginan untuk menikah, karena merasa tidak ada target lagi (seperti harus tuntas sekolah pendidikan dasar) melainkan hanya bekerja. Terbukti dari semua pelaku pernikahan di bawah umur yang berhasil diwawancarai, 23 diantaranya hanyalah tamatan Sekolah Dasar, 17 diantaranya berhenti sekolah ketika ditawari menikah saat menempuh pendidikan Sekolah Menengah Pertama, dan 3 diantaranya hanyalah lulusan Sekolah Menengah Pertama dan tidak melanjutkan ke pendidikan Sekolah Menengah Atas. ${ }^{30}$ Menanggapi hal itu, khsunul mengatakan: "Untuk apa sekolah tinggi-tinggi, yang lain kan juga berpendidikan rendah. Lebih baik menikah, lebih pasti." ${ }^{1}$

Karena rata-rata pendidikan rendah inilah, mereka tidak mengerti (tidak mau mengerti) tentang implikasi negatif dari pernikahan yang dilakukan di bawah umur, seperti bahaya pada kandungan ibu, belum matangnya fisik dan psikis calon mempelai, dan ekonomi yang belum mapan. Jika mereka sekolah mungkin mereka akan belajar Biologi yang mengkaji tentang reproduksi (yang sehat), sehingga mereka tahu bahaya hamil pada usia yang terlalu muda. Namun karena mereka tidak mementingkan pendidikan, maka praktek pernikahan di bawah umur yang dapat membahayakan ibu hamil di usia muda ini seolah tidak bertentangan dengan apapun. ${ }^{32}$

${ }^{30}$ Kesimpulan ini penyusun dapatkan berdasarkan survey langsung di Desa Wedusan selama bulan November 2015.

${ }^{31}$ Wawancara dengan Rusydi, Pelaku Pernikahan di bawah Umur, Wedusan, Tiris, Probolinggo, Tanggal 7 November 2015.

32 Agar tidak berbahaya bagi ibu dan janin, maka kehamilan itu harus pada saat uterus sudah kuat yaitu biasanya saat ibu berusia 20 tahun keatas (J.P. Greenhill dan Emanuel A. Friedman, 1974: 95-96; Badan Pemberdayaan Perempuan dan Masyarakat Daerah Istimewa Yogyakarta, 2009: 62-64). 


\section{Faktor Perjodohan (Titah Orang Tua)}

Di kalangan masyarakat pedesaan, masih berlaku tradisi yang hampir mengambil semua hak kemerdekaan seorang gadis untuk memilih suaminya. Biasanya anak itu didikte untuk menikah dengan seseorang yang disenangi oleh orang tuanya, disamping itu juga karena kondisi masyarakat tempat ia dibesarkan yang tidak membolehkan anak membantah kehendak orang tua atau walinya. Menurut Roberta Edwards Lenkeit, pernikahan di kelompok masyarakat tradisional (pedesaan) cenderung berdasarkan campur tangan orang tua. Sekuat apapun anak itu menolak, kalau orang tuanya sudah berkehendak, maka anak itu tidak bisa bertindak dan tidak boleh menolak (Lenkeit, 2004: 150-159). Perkawinan yang demikian sering kali mengecewakan dan memaksa si anak merasakan kepahitan (Nasution (ed.), 1977: 51).

Di Desa Wedusan, biasanya orang tua ingin menikahkan anaknya dengan anak temannya, agar hubungan kekerabatan (bisnis dan lain sebagainya) masih tetap terjalin. Bahkan yang lebih parah lagi, katanya anak yang baru lahir saja sudah dipesan oleh temannya untuk dinikahkan dengan anaknya. "Saya sudah menjodohkan anak saya dengan anak besan sudah sejak anak saya masih kecil, agar dia "tidak ke mana-mana." 33

Pengaruh budaya patriarkat, mendesak anak untuk selalu patuh kepada keputusan bapak, kalau tidak patuh bisa kualat. Kalau misalkan anak tersebut nanti sudah besar ternyata berlabuh ke lain hati, artinya tidak suka dengan pasangan pilihan orang tuanya tersebut, maka orang tua itu biasanya datang ke Kyai untuk minta jampi-jampi atau meminta pertolongan untuk mendoakan agar anaknya bisa suka kepada pasangan pilihannya (orang tua). ${ }^{34}$ Untuk mencegah hal ini, orang tua harus segera menikahkan anaknya, karena anak yang masih kecil lebih mudah untuk dipengaruhi. "Kalau sudah dijodohkan ya segera dinikahkan, takut ada fitnah, lagian kalau anak masih kecil itu kan bisa disuruh suruh." 35

Dari 43 (empat puluh tiga) kasus pernikahan di bawah umur yang

${ }^{33}$ Wawancara dengan Mushlihah, Orang tua pelaku Pernikahan di bawah Umur, Wedusan, Tiris, Probolinggo, tanggal 6 November 2015.

${ }^{34}$ Wawancara dengan Romdlon, Orang tua pelaku Pernikahan di bawah Umur, Wedusan, Tiris, Probolinggo, tanggal 14 November 2015.

35 Wawancara dengan Zaidi, Orang tua pelaku Pernikahan di bawah Umur, Wedusan, Tiris, Probolinggo, tanggal 14 November 2015. 
ada, 27 (dua puluh tujuh) diantaranya bermodus perjodohan, karena mayoritas pelaku pernikahan dibawah umur di Desa Wedusan ini adalah wanita. "Saya dulu itu kan masih anak-anak, jadi nurut saja apa kata orang tua." 36

\section{Faktor Hasrat Pribadi}

Pernikahan di bawah umur di Desa Wedusan disamping karena faktor eksternal, seperti pengaruh budaya dan orang tua tersebut, ada juga yang disebabkan oleh faktor internal calon mempelai sendiri. Ada beberapa anak yang sejak sedang menuntut ilmu di sekolah sudah berpacaran dengan lawan jenisnya. Mungkin karena sudah merasa saling cocok dan takut tergoda oleh hal-hal yang tidak diinginkan, akhirnya keduanya pun memohon kepada orang tuanya agar direstui untuk menikah. "Karena sudah saling kenal sejak SD, akhirnya pada kelas dua SMP kami memohon kepada orang tua untuk direstui menikah, karena mereka merestui, maka kita jadi menikah satu tahun kemudian, yaitu tanggal 20 Juni 2011." 37

Dari 43 kasus pernikahan di bawah umur yang ada, 9 (sembilan) diantaranya adalah disebabkan karena hasrat pribadi calon mempelai sendiri. "Saya dulu menikah muda karena takut hubungan kami terusik oleh orang lain, soalnya istri saya ini adalah bunga desa." 38

\section{Hasil Penelitian}

a. Data Penelitian

\begin{tabular}{|c|c|c|c|}
\hline $\begin{array}{c}\text { No. } \\
\text { Responden }\end{array}$ & $\begin{array}{c}\text { Keharmonisan } \\
\text { Rm Tangga (Y) }\end{array}$ & $\begin{array}{c}\text { Pendapatan } \\
\text { Ekonomi }\left(\mathbf{X}_{\mathbf{1}}\right)\end{array}$ & $\begin{array}{c}\text { Kedewasaan } \\
\text { Pasangan }\left(\mathbf{X}_{2}\right)\end{array}$ \\
\hline 1 & 24 & 23 & 25 \\
\hline 2 & 30 & 28 & 30 \\
\hline 3 & 24 & 28 & 25 \\
\hline 4 & 27 & 26 & 26 \\
\hline
\end{tabular}

${ }^{36}$ Wawancara dengan H. Utsman, Pelaku Pernikahan di bawah Umur, Wedusan, Tiris, Probolinggo, tanggal 8 November 2015.

37 Wawancara dengan H.Hasan, Pelaku Pernikahan di bawah Umur, Wedusan, Tiris, Probolinggo, tanggal 12 November 2015.

38 Wawancara dengan Karim, Pelaku penikahan di bawah umur, Wedusan, Tiris, Probolinggo, tanggal 11 November 2015. 


\begin{tabular}{|c|c|c|c|}
\hline $\begin{array}{c}\text { No. } \\
\text { Responden }\end{array}$ & $\begin{array}{l}\text { Keharmonisan } \\
\text { Rm Tangga (Y) }\end{array}$ & $\begin{array}{c}\text { Pendapatan } \\
\text { Ekonomi }\left(\mathrm{X}_{1}\right)\end{array}$ & $\begin{array}{c}\text { Kedewasaan } \\
\text { Pasangan }\left(\mathrm{X}_{2}\right)\end{array}$ \\
\hline 5 & 25 & 31 & 26 \\
\hline 6 & 25 & 28 & 25 \\
\hline 7 & 24 & 28 & 25 \\
\hline 8 & 29 & 28 & 28 \\
\hline 9 & 31 & 27 & 25 \\
\hline 10 & 24 & 27 & 27 \\
\hline 11 & 31 & 26 & 29 \\
\hline 12 & 24 & 28 & 28 \\
\hline 13 & 28 & 32 & 25 \\
\hline 14 & 23 & 21 & 19 \\
\hline 15 & 27 & 27 & 22 \\
\hline 16 & 30 & 26 & 23 \\
\hline 17 & 29 & 30 & 24 \\
\hline 18 & 25 & 22 & 18 \\
\hline 19 & 24 & 26 & 18 \\
\hline 20 & 25 & 24 & 19 \\
\hline 21 & 24 & 27 & 23 \\
\hline 22 & 24 & 23 & 22 \\
\hline 23 & 28 & 29 & 22 \\
\hline 24 & 29 & 26 & 21 \\
\hline 25 & 28 & 29 & 22 \\
\hline 26 & 23 & 21 & 29 \\
\hline 27 & 24 & 27 & 28 \\
\hline 28 & 24 & 22 & 24 \\
\hline 29 & 28 & 31 & 29 \\
\hline 30 & 27 & 26 & 31 \\
\hline 31 & 28 & 28 & 28 \\
\hline 32 & 30 & 26 & 28 \\
\hline 33 & 29 & 28 & 27 \\
\hline 34 & 27 & 25 & 30 \\
\hline 35 & 28 & 27 & 24 \\
\hline 36 & 33 & 30 & 29 \\
\hline 37 & 32 & 31 & 28 \\
\hline 38 & 26 & 25 & 26 \\
\hline 39 & 31 & 31 & 31 \\
\hline
\end{tabular}




\begin{tabular}{|c|c|c|c|}
\hline $\begin{array}{c}\text { No. } \\
\text { Responden }\end{array}$ & $\begin{array}{c}\text { Keharmonisan } \\
\text { Rm Tangga (Y) }\end{array}$ & $\begin{array}{c}\text { Pendapatan } \\
\text { Ekonomi }\left(\mathbf{X}_{\mathbf{1}}\right)\end{array}$ & $\begin{array}{c}\text { Kedewasaan } \\
\text { Pasangan }\left(\mathbf{X}_{2}\right)\end{array}$ \\
\hline 40 & 26 & 29 & 32 \\
\hline 41 & 25 & 24 & 27 \\
\hline 42 & 24 & 24 & 27 \\
\hline 43 & 27 & 25 & 28 \\
\hline
\end{tabular}

\section{b. Analisis Deskriptif Data}

Dalam penelitian ini, peneiti menuji tingkat asosiasi atau hubungan yang terjadi antar variabel menggunakan bantuan program aplikasi W-Stats versi 2011 (Prof. Ibnu Hajar), dan didapatkan hasil sebagai berikut:

\begin{tabular}{|l|c|c|c|c|c|c|c|c|}
\hline \multicolumn{1}{|c|}{ Variabel } & & $\mathbf{N}$ & $\begin{array}{c}\text { Ter- } \\
\text { tinggi }\end{array}$ & $\begin{array}{c}\text { Ter- } \\
\text { rendah }\end{array}$ & Rerata & Varian & $\begin{array}{c}\text { Simpang } \\
\text { Baku }\end{array}$ & $\begin{array}{c}\text { Galat } \\
\text { Baku }\end{array}$ \\
\hline $\begin{array}{l}\text { Keharmonisan } \\
\text { Rumah Tangga }\end{array}$ & $\mathrm{Y}$ & 43 & 33 & 23 & 26,837 & 7,378 & 2,716 & 0,414 \\
\hline $\begin{array}{l}\text { Pendapatan } \\
\text { Ekonomi }\end{array}$ & $\mathrm{X}_{1}$ & 43 & 32 & 21 & 26,744 & 7,719 & 2,778 & 0,424 \\
\hline $\begin{array}{l}\text { Kedewasaan } \\
\text { Pasangan }\end{array}$ & $\mathrm{X}_{2}$ & 43 & 32 & 18 & 25,419 & 13,392 & 3,660 & 0,558 \\
\hline
\end{tabular}

\section{1) Pendapatan Ekonomi}

Dari hasil analisis deskriptif menggnakan W-Stats atas data yang diperoleh, peneliti dapat jelaskan bahwa skor terendah variabel pendapatan ekonomi dengan responden 43 orang adalah 21, skor tertinggi 32, nilai rata-rata 26,744; varian 7,719: simpang baku 2,778; dan galat baku 0,424. Dengan demikian dari nilai rerata tersebut dapat disimpulkan bahwa data pendapatan ekonomi pelaku pernikahan di bawah umur di Desa Wedusan terdistribusi secara normal karena penyebaran data berdasarkan nilai simpang baku (standar deviasi) lebih besar dari taraf signifikasi yang digunakan yaitu $5 \%$. 


\section{2) Kedewasaan Pasangan}

Peneliti dapat jelaskan bahwa skor terendah variabel kedewasaan pasangan adalah 21 skor tertinggi 32, nilai rata-rata 25,419; varian 13,392: simpang baku 3,66; dan galat baku 0,558. Maka penyebaran data mengenai kedewasaan pasangan pelaku pernikahan di bawah umur di Desa Wedusan terdistribusi normal.

3) Keharmonisan Rumah Tangga

Peneliti dapat jelaskan bahwa skor terendah variabel keharmonisan rumah tangga adalah 23 skor tertinggi 33, nilai rata-rata 26,837; varian 7,378: simpang baku 2,716; dan galat baku 0,414. Dengan demikian dari nilai simpang baku tersebut dapat disimpulkan bahwa keharmonisan rumah tangga pelaku pernikahan di bawah umur di Desa Wedusan juga terdistribusi normal.

\section{c. Analisis Regresi Ganda}

\begin{tabular}{|c|c|c|c|c|l|}
\hline MODEL & B & $\mathbf{t}$ & d.k. & $\begin{array}{c}\text { t-Kritis pd } \\
\text { taraf sign. } \\
\mathbf{0 , 1 \%}\end{array}$ & Kesimpulan \\
\hline Konstan (a) & 11,54 & & & & \\
\hline$X_{1}$ & 0,431 & 2,987 & 40 & 3,788 & $\begin{array}{l}\text { Tidak } \\
\text { Signifikan }\end{array}$ \\
\hline$X_{2}$ & 0,148 & 1,351 & 40 & 3,788 & $\begin{array}{l}\text { Tidak } \\
\text { Signifikan }\end{array}$ \\
\hline
\end{tabular}

Gambar 7. Hasil Uji Koefisien Regresi

Berdasarkan hasil analisis regresi ganda dengan menggunakan program W-Stats pada tabel diatas, diperoleh koefisien untuk variabel bebas $X_{1}=0,431, X_{2}=0,148$ dan konstanta sebesar 11,54 sehingga model persamaan regresi yang diperoleh adalah:

$$
\begin{aligned}
Y^{\prime} & =a+b_{1} X_{1}+b_{2} X_{2} \\
& =11,54+0,431 X_{1}+0,148 X_{2}
\end{aligned}
$$




\section{Keterangan :}

$\mathrm{Y}^{\prime}=$ Skor Y yang diprediksikan

$\mathrm{a}=$ intersep

$\mathrm{b}_{1}=$ Slop variabel $\mathrm{X}_{1}$

$\mathrm{b}_{2}=$ Slop variabel $\mathrm{X}_{2}$

$\mathrm{X}_{1}=$ Skor variabel $\mathrm{X}_{1}$

$\mathrm{X}_{2}=$ Skor variabel $\mathrm{X}_{2}$

\section{Penjelasan :}

1. Konstanta menunjukkan angka 11,54 yang merupakan estimasi keharmonisan rumah tangga jika pendapatan dan kedewasaan pasangan adalah nol. Artinya jika pendapatan ekonomi ataupun kedewasaan pasangan tidak ada atau tidak mengalami perubahan nilai, maka tingkat keharmonisan rumah tangga adalah tetap sebesar 11,54.

2. Koefisien regresi pendapatan ekonomi sebesar 0,431, artinya jika pendapatan ekonomi mengalami kenaikan satu satuan, maka tingkat keharmonisan rumah tangga mengalami peningkatan sebesar 0,431 satuan dengan asumsi variabel independen lainnya bernilai tetap dengan asumsi koefisien kedewasaan pasangan adalah nol. Nilai konstanta yang positif menunjukkan bahwa hubungan yang terjadi antara variabel bebas dan variabel terikat bersifat searah.

3. Koefisien regresi kedewasaan pasangan sebesar 0,148, artinya jika kedewasaan pasangan mengalami peningkatan satu satuan, maka tingkat keharmonisan rumah tangga akan mengalami peningkatan sebesar 0,148 satuan dengan asumsi variabel independen lainnya bernilai nol. Nilai konstanta ini juga menunjukkan hasil positif yang menunjukkan bahwa hubungan yang terjadi antara variabel bebas dan variabel terikat juga searah.

\section{d. Analisis Korelasi}

Koefisien Korelasi

Pendapatan Ekonomi dan Keharmonisan Rumah Tangga 0,862

Kedewasaan Pasangan dan Keharmonisan Rumah Tangga 0,642

Pendapatan Ekonomi dan Kedewasaan Pasangan 


\section{Koefisien Korelasi Parsial}

Pendapatan Ekonomi dan Keharmonisan Rumah Tangga $\quad 0,753$ Kedewasaan Pasangan dan Keharmonisan Rumah Tangga $\quad$ 0,090

\begin{tabular}{|c|c|c|c|c|l|}
\hline MODEL & B & $\mathbf{t}$ & d.k. & $\begin{array}{c}\text { t-Kritis pd } \\
\text { taraf sign. } \\
\mathbf{0 , 1 \%}\end{array}$ & Kesimpulan \\
\hline Konstan (a) & 11,54 & & & & \\
\hline$X_{1}$ & 0,431 & 2,987 & 40 & 3,788 & $\begin{array}{l}\text { Tidak } \\
\text { Signifikan }\end{array}$ \\
\hline$X_{2}$ & 0,148 & 1,351 & 40 & 3,788 & $\begin{array}{l}\text { Tidak } \\
\text { Signifikan }\end{array}$ \\
\hline
\end{tabular}

\section{Pengujian koefisien regresi variabel Pendapatan Ekonomi} $\left(\mathrm{X}_{1}\right)$

Ho = Pendapatan ekonomi pasangan tidak berkorelasi signifikan terhadap keharmonisan rumah tangga pelaku pernikahan di bawah umur di Desa Wedusan.

$\mathrm{Ha}=$ Pendapatan ekonomi pasangan berkorelasi signifikan terhadap keharmonisan rumah tangga pelaku pernikahan di bawah umur di Desa Wedusan.

Berdasarkan output diperoleh $t_{\text {hitung }}$ sebesar 2,987 dan hasil yang diperoleh untuk $t_{\text {kritis }}$ sebesar 3.788. Karena nilai $t_{\text {hitung }}$ kurang dari $t_{\text {kritis }}$, maka Ho diterima dan variabel X1 dinyatakan tidak signifikan. Dengan kata lain, dapat dikatakan bahwa secara sederhana hipotesis yang menyatakan terdapat hubungan yang signifikan secara parsial antara pendapatan ekonomi dengan keharmonisan rumah tangga pelaku pernikahan di bawah umur di Desa Wedusan ditolak dan teruji tidak signifikan. Kesimpulan ini memberikan arti bahwa setiap peningkatan satu satuan pendapatan ekonomi saja (secara parsial) tidak dapat meningkatkan keharmonisan rumah tangga.pelaku pernikahan di bawah umur di Desa Wedusan. 


\section{Pengujian koefisien regresi variabel Kedewasaan Pasangan $\left(\mathrm{X}_{2}\right)$}

Ho $=$ Kedewasaan pasangan tidak berkorelasi signifikan terhadap keharmonisan rumah tangga pelaku pernikahan di bawah umur di Desa Wedusan.

$\mathrm{Ha}=$ Kedewasaan pasangan berkorelasi signifikan terhadap keharmonisan rumah tangga pelaku pernikahan di bawah umur di Desa Wedusan.

Berdasarkan output W-Stats@2011 diperoleh $\mathrm{t}_{\text {hitung }}$ sebesar 1,351. $t_{\text {hitung }}$ kedewasaan pasangan menunjukkan bahwa nilainya juga tidak lebih besar atau kurang dari $\mathrm{t}_{\text {kritis }}$ yaitu 3.788. Karena nilai $t_{\text {hitung }}$ berada diwilayah $t_{\text {kritis }}$ maka $\mathrm{Ha}$ ditolak dan Ho dierima. Dengan kata lain, dapat dikatakan bahwa lewat uji regresi sederhana (parsial) hipotesis yang menyatakan terdapat hubungan yang signifikan antara kedewasaan pasangan dengan keharmonisan rumah tangga pelaku pernikahan di bawah umur ditolak dan teruji tidak signifikan. Kesimpulannya, kedewasaan pasangan secara parsial tidak berkorelasi signifikan terhadap tingkat keharmonisan rumah tangga pelaku pernikahan di bawah umur di Desa Wedusan.

3. Uji koefisien regresi secara simultan (F)

\begin{tabular}{|l|r|r|c|c|r|r|}
\hline $\begin{array}{l}\text { Sumber } \\
\text { Varian }\end{array}$ & JK & DK & RK & Fhit & $\begin{array}{r}\mathrm{F}_{\text {krit }} \text { Pd trf } \\
\text { Sign. 0,1\% }\end{array}$ & $\begin{array}{c}\text { Kesim- } \\
\text { pulan }\end{array}$ \\
\hline Regresi & 239,736 & 2 & 119,868 & 58,549 & 9,247 & Signifikan \\
\cline { 1 - 5 } Residu & 81,892 & 40 & 2,047 & & & \\
\cline { 1 - 5 } Total & 321,628 & 42 & & & & \\
\hline
\end{tabular}

Ho = Pendapatan Ekonomi dan Kedewasaan Pasangan tidak berpengaruh secara simultan terhadap keharmonisan rumah tangga pelaku pernikahan di bawah umur di Desa Wedusan. $\mathrm{Ha}=$ Pendapatan Ekonomi dan Kedewasaan Pasangan berpengaruh secara simultan terhadap keharmonisan rumah tangga pelaku pernikahan di bawah umur di Desa Wedusan. 
Berdasarkan output diperoleh $\mathrm{F}_{\text {hitung }}$ sebesar 58,549, sedangkan hasil yang diperoleh untuk $\mathrm{F}_{\text {kritis }}$ sebesar 3,23. Karena nilai $\mathrm{F}_{\text {hitung }}>$ $\mathrm{F}_{\text {kritis }}$, maka Ho ditolak sedangkan $\mathrm{H}_{\mathrm{a}}$ diterima. Dengan kata lain, dapat dikatakan bahwa hipotesis yang menyatakan terdapat hubungan yang positif signifikan antara pendapatan ekonomi dan kedewasaan dengan keharmonisan rumah tangga diterima dan teruji signifikan. Kesimpulan ini memberikan arti bahwa setiap peningkatan satu satuan skor variabel pendapatan ekonomi $\left(\mathrm{X}_{1}\right)$ dan kedewasaan pasangan $\left(X_{2}\right)$ secara bersamaan akan dapat meningkatkan skor variabel keharmonisan rumah tangga pelaku pernikahan dini bawah umur di Desa Wedusan (Y).

\section{Koefisien Determinasi (Adjusted $\mathrm{R}^{2}$ )}

Sumbangan pada Varian

Sumbangan Variabel

Pendapatan Ekonomi

Kedewasaan Pasangan

Pendapatan Ekonomi dan Kedewasaan Pasangan

Kedewasaan Pasangan setelah Pendapatan Ekonomi

Pendapatan Ekonomi setelah Kedewasaan Pasangan
Keharmonisan Rumah Tangga

$\mathrm{R}^{2}$

0,285

0,164

0,316

0,031

0,152

Berdasarkan perhitungan yang dilakukan dengan menggunakan program W-Stats, dapat terlihat bahwa secara bersama-sama, sumbangan pendapatan ekonomi dan kedewasaan pasangan terhadap keharmonisan rumah tangga pelaku pernikahan di bawah umur di Desa Wedusan yang ditunjukkan oleh perhitungan $\mathrm{R}^{2}$ sebesar 0,316 atau 31,6\%. Ini menunjukkan bahwa presentase pengaruh variabel independen, yaitu pendapatan ekonomi dan kedewasaan pasangan terhadap variabel tingkat keharmonisan rumah tangga pelaku pernikahan di bawah umur di Desa Wedusan hanyalah 31,6\%. Hal ini menunjukkan bahwa meski terdapat korelasi yang signifikan antara pendapatan ekonomi dan kedewasaan pasangan dengan keharmonisan rumah tangga pelaku pernikahan di bawah umur di Desa Wedusan, namun sumbangan signifikansi korelasinya sangatlah rendah. Maka bisa diartikan bahwa ada faktor lain yang lebih besar korelasinya 
terhadap keharmonisan rumah tangga di luar dua variabel tersebut, mungkin karena faktor lingkungan, budaya patriarkat, pola komunikasi rumah tangga, atau faktor yang lain.

\section{e. Pembahasan Hasil Penelitian}

Berdasarkan hasil analisis deskriptif, dapat dijelaskan bahwa data pendapatan ekonomi, kedewasaan pasangan, serta keharmonisan rumah tangga pelaku pernikahan di bawah umur di Desa Wedusan terdistribusi normal.

Variabel pendapatan ekonomi $\left(\mathrm{X}_{1}\right)$ dan kedewasaan pasangan $\left(\mathrm{X}_{2}\right)$ dengan pengujian secara parsial memiliki hubungan yang tidak signifikan dengan keharmonisan rumah tangga pasangan pelaku pernikahan di bawah umur. Namun secara bersamaan memiliki hubungan yang signifikan.

Artinya, pelaku pernikahan di bawah umur akan tetap harmonis meski tidak dewasa, namun memiliki pendapatan ekonomi yang baik, demikian pula sebaliknya. Dan jika mereka tidak baik dalam keduanya, pendapatan ekonomi dan kedewasaan pasangan, maka mereka akan tidak harmonis.

Keharmonisan rumah tangga memiliki keterkaitan dengan pendapatan ekonomi dan kedewasaan secara simultan dengan hasil yang positif. Dengan kata lain, dapat dikatakan bahwa keharmonisan rumah tangga akan cenderung meningkat apabila pendapatan ekonomi dan kedewasaan juga meningkat secara bersamaan. Sebaliknya, apabila pendapatan ekonomi dan kedewasaan menurun, maka keharmonisan rumah tangga cenderung menurun. Oleh karena itu, peningkatan keharmonisan rumah tangga harus didahului dengan peningkatan pendapatan ekonomi dan kedewasaan.

\section{f. Kesimpulan}

Berdasarkan hasil penelitian dan pembahasan pada bab-bab sebelumnya, penelitian ini dapat disimpulkan sebagai berikut:

1) Tidak terdapat korelasi yang signifikan antara pendapatan ekonomi dengan keharmonisan rumah tangga di Desa Wedusan. Hal ini dapat dilihat dari hasil nilai korelasi yang diperoleh yang dirumuskan $\mathrm{t}_{\text {hitung }}=2,987<\mathrm{t}_{\text {kritis }}=3,788$ pada taraf signifikasi 
5\%. Dengan demikian, apabila pendapatan ekonomi tidak naik, keharmonisan rumah tangga belum tentu menurun. Demikian juga apabila pendapatan ekonomi turun, keharmonisan rumah tangga belum tentu menjadi rendah.

2) Tidak terdapat korelasi yang signifikan antara kedewasaan pasangan dengan keharmonisan rumah tangga pelaku pernikahan di bawah umur di Desa Wedusan, Tiris, Probolinggo. Hal ini dapat dilihat dari hasil nilai korelasi yang diperoleh yang dirumuskan $\mathrm{t}_{\text {hitung }}=1,351<\mathrm{t}_{\text {kritis }}=3,788$ pada taraf signifikasi $5 \%$. Dengan demikian, apabila kedewasaan pasangan tidak naik, keharmonisan rumah tangga belum tentu menurun. Demikian juga apabila kedewasaan pasangan turun, keharmonisan rumah tangga juga belum tentu menjadi rendah.

3) Terdapat korelasi yang signifikan secara bersama-sama antara pendapatan ekonomi dan kedewasaan pasangan dengan keharmonisan rumah tangga di Desa Wedusan. Hal ini dapat dilihat dari hasil nilai korelasi yang diperoleh yang dirumuskan $\mathrm{F}_{\text {hitung }}=9,249>\mathrm{F}_{\text {kritis }}=9,247$ pada taraf signifikasi 5\%. Dengan demikian, apabila pendapatan ekonomi dan kedewasaan pasangan naik secara bersama-sama, keharmonisan rumah tangga akan meningkat. Sebaliknya, apabila pendapatan ekonomi dan kedewasaan pasangan menurun secara bersamasama, keharmonisan rumah tangga akan menurun. 


\section{DAFTAR PUSTAKA}

Amin, M. Masyhur dan M. Nasikh Ridwan, 1996, K.H. Zaini Mun'im; Pengabdian dan Karya Tulisnya, Yogyakarta: LKPSM.

Asmawi, Mohammad, 2004, Nikah Dalam Perbincangan dan Perbedaan, Yogyakarta: Darussalam.

Azwar, Saifuddin, Metode Penelitian, Yogyakarta: Pustaka Pelajar, 1998.

Badan Pemberdayaan Perempuan dan Masyarakat Daerah Istimewa Yogyakarta, 2009, Modul Bagi Fasilitator: Kesehatan Reproduksi Remaja, Yogyakarta: BPPM D.I. Yogyakarta.

BPS Kabupaten Probolinggo, 2010, Kabupaten Probolinggo dalam Angka 2010, Probolinggo: BPS Kabupaten Probolinggo.

BPS Kabupaten Probolinggo, 2010, Kecamatan Tiris dalam Angka 2010, Probolinggo: BPS Kabupaten Probolinggo.

BPS Provinsi Jawa Timur, 2010, Provinsi Jawa Timur dalam Angka 2010, Surabaya: BPS Provinsi Jatim.

Bukhârî al-, Muhammad Ibn Ismail, t.t., Sahih Bukhârî, Beirut: Dâr alFikr, VI.

Dachlan, NJ. Aisjah, 1969, Membina Rumah Tangga Bahagia dan Peranan Agama dalam Rumah Tangga, Jakarta: Jamunu.

Daradjat, Zakiah, 1970, Ilmu Djiwa Agama, Jakarta: Bulan Bintang.

Desmita, 2005, Psikologi Perkembangan, Bandung: PT. Remaja Rosdakarya.

Feldman, Robert S., 1996, Understanding Psychology, New York: McGraw Hill.

Greenhill, J.P. dan Emanuel A. Friedman, 1974, Biological Principals and Modern Practice of Obstetries, London: W.B. Sanders Company.

H. Mahmud Yunus, 1989, Kamus Yunus, Jakarta: Hidakarya Agung.

Hadjar, Ibnu, 2011, Dasar-Dasar Statistik untuk Ilmu Pendidikan Sosial 8 Humaniora, Semarang: Fak. Tarbiyah IAIN Walisongo. 
Hakimi, Mohammad, 1990, Ilmu Kebidanan: Fisiologi dan Patologi Persalinan, Jakarta: Essentia Medica.

Harahap, Syahrin, 1996, Islam Dinamis : Menegakkan Nilai-Nilai Ajaran Al-Qur'an dalam Kehidupan Modern Di Indonesia, Yogyakarta: Tiara Wacana.

Hardy, Malcolm dan Steve Heyes, 1985, Pengantar Psikologi Edisi Kedua, terj. Soenardji, Jakarta: Erlangga.

Indra, Hasbi, dkk., 2004, Potret Wanita Shalehah, Jakarta: Penamadani.

J.P. Chaplin, 2006, Kamus Lengkap Psikologi, terj. Kartini Kartono, Jakarta: PT. Raja Grafindo Persada.

Jersild, Arthur T., 1962, Child Psychology, terj. Conny Setiawan, Bandung: Tarate.

Johnson, Doyle Paul, 1986, Teori Sosiologi Klasik dan Modern, terj. Robert M. Z. Lawang, Jakarta: PT. Gramedia.

Kamaluddin, Ahmad, 1993, Bina Keluarga Sakinah Menangkal Kenakalan Remaja. Majalah Perkawinan dan Keluarga. No. 285 / Th. XXII / Desember.

Koentjaraningrat, 1987, Sejarah Teori Antropologi I, Jakarta: UI Press.

Knox, David, t.t., Choices in Relationship; An Introdution to Marriage and the Family, Edisi Ke-2, New York: Web Publishing Company.

Kuntowijoyo, 1993, Esei-Esei Sejarah "Radikalisme Petani", Yogyakarta: Bentang Intervisi Utama.

L.,Zulkifli, 2006, Psikologi Perkembangan, Bandung: PT. Remaja Rosdakarya.

Lenkeit, Roberta Edwards, 2004, Introducing Cultural Anthropology, edisi ke-2, New York: McGraw-Hill.

Mahmood, Tahir, 1972, Family Law Reform in The Muslim World, Bombay: N.M. Tripathi PVT.LTD.

Mappiare, Andi, 1983, Psikologi Orang Dewasa Bagi Penyesuaian dan Pendidikan, Surabaya: Usaha Nasional. 
Mc Bee, Elizabeth A., 1982, Too Little Too Late: Services for Teenage Parents, New York: Ford Foundation.

Mochtar, Rustam, 1989, Sinopsis Obstetri; Obstetri Operatif, Obstetri Sosial II, Jakarta: EGC.

Munawwir, Ahmad Warson, 1997, Kamus al-Munawir, cet. Ke-14, Yogyakarta: Pustaka Progressif.

Nasution, Khoiruddin, 2005, Hukum Perkawinan I: Dilengkapi Perbandingan UU Negara Muslim Kontemporer, Yogyakarta: Academia + Tazzafa.

Nu'aimi an-, Thariq Kamal, 2005, Psikologi Suami Istri: Memahami Perbedaan Tabiat dan Karakter Seksis Laki-Laki dan Perempuan Demi Membangun Keharmonisan Hidup Berkeluarga, terj. Muh. Muhaimin, Yogyakarta: Mitra Pustaka.

Nuruddin, Amir dan Azhari Akmal Taringan, 2004, Hukum Perdata Islam di Indonesia (Studi Kritis Perkembangan Hukum Islam dari Fikih, UU. No.1/1974 sampai KHI), Jakarta: Kencana.

Nye, F. Ivan, 1976, "Role Constructs: Measurement," dalam Jetse Sprey (ed.), Role Structure and Analysis of the Family, London: Sage Publications.

Osho, 2004, Intelligence: The Creative Response to Now, New York: St. Martin's Griffin.

Peter Salim dan Yenny Salim, 1991, Kamus Bahasa Indonesia Kontemporer, Jakarta: Modern English Press.

Pius A. Partanto dan M. Dahlan Al-Barry, 1994, Kamus Ilmiah Populer, Surabaya: Arkola.

Pohan, M. Imran, dkk., 1968, Psikologi anak, Jakarta: Circarama.

Pusat Pembinaan dan Pengembangan Bahasa DEPDIKBUD, 1985, Kamus Umum Bahasa Indonesia, Jakarta: Balai Pustaka.

Santrock, John W., 2003, Adolescence: Perkembangan Remaja, terj. Shinto B. Adelar dan Sherly Saragih, Jakarta: Erlangga. 
Santrock, John W., 2002, Life-Span Development: Perkembangan Masa Hidup, Edisi 5, terj. Achmad Chusairi dan Juda Damanik, Jakarta: Erlangga.

Sarwono, Sarlito Wirawan, 1978, Berkenalan dengan Aliran-Aliran dan Tokoh-Tokoh Psikologi, Jakarta: Bulan Bintang.

Shihab, Quraish, 1996, Wawasan al-Qur'an: Tafsir Maudhu'i atas Pelbagai persoalan Ummat, Bandung: Mizan.

Sigelman, Carol K. dan David R. Shaffer, 1995, Life Span Human Development, California: Brooks/Cole Publishing Company.

Sosroatmodjo dan H.A. Wasit Aulawi, 1978, Hukum Perkawinan di Indonesia, Jakarta: Bulan Bintang.

Tirmidzî at-, Abu Isâ Muhammad Ibnu Isâ, t.t., Sunân at-Tirmidzî, Beirut: Dâr al-Fikr, II.

Walgito, Bimo, 1981, Pengantar Psikologi Umum, Yogyakarta: Andi Offset.

Witherington, H. Carl, 1982, Psikologi Pendidikan, terj. M. Buchori, Bandung: Jemmars.

Yusuf, H. Syamsu, 2004, Psikologi Perkembangan Anak dan Remaja, cet. ke-5, Bandung: PT. Remaja Rosdakarya.

Zuhailî az-, Wahbah, 1989, al-Fiqh al-Islâmî wa adillatuhu, cet. Ke-3, Beirut: Dâr al-Fikr, VII. 